\section{Cloning and Purification of Bacteriophage K11 RNA Polymerase}

\section{BioTechniques 27:690-694 (October 1999)}

Bacteriophage T7 is the prototype of a group of bacterial viruses that each encode a single subunit DNA-dependent RNA polymerase (RNAP). Other members of this class include the coliphages T3 and BA14, the Salmonella phage SP6, the Pseudomonas phage gh1 and the Klebsiella phage K11 $(9,16)$. The phage RNA polymerases have proven to be useful in a variety of applications, including large-scale RNA synthesis, nucleic acid amplification and as the basis for efficient expression systems in both prokaryotic and eukaryotic cells $(5,7,8,15,23,24,26)$. To facilitate these applications, the T7, T3 and SP6 RNA polymerases have been cloned $(2,11,12,17,24)$ and more recently have been expressed as histidine-tagged fusion proteins, which greatly simplifies their purification $(1,6,10)$.

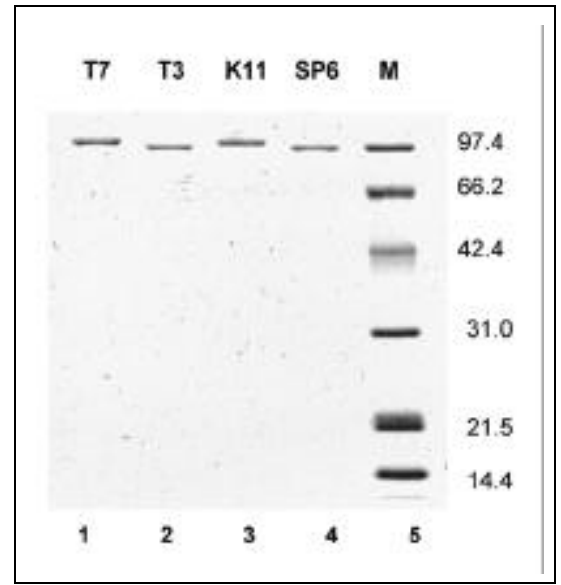

Figure 1. Purification of His-tagged phage RNAPs. Cultures of pBH161, pBH118, pBH176 and pMR105, which express his-tagged T7, T3, SP6 and K11 RNAPs, respectively (10) were induced with IPTG, and the RNAPs were purified by affinity chromatography on $\mathrm{Ni}^{++}$-agrarose beads. An aliquot containing $0.5 \mu \mathrm{g}$ of each RNAP was analyzed by electrophoresis in $10 \%$ polyacrylamide gels. We estimate that the samples are more than $90 \%$ pure, as judged by the absence of significant extraneous bands after staining with Coomassie ${ }^{\circledR}$ Blue (10,21). Lane 1, T7 RNAP; lane 2, T3 RNAP; lane 3, K11 RNAP; lane 4, SP6 RNAP; lane 5, molecular-weight markers (low range; sizes are given in the margin in $\mathrm{kDa}$; Bio-Rad, Hercules, CA, USA).
In this work, we describe the expression and purification of a histidinetagged form of the RNA polymerase encoded by bacteriophage K11. The availability of K11 RNAP furnishes opportunities for additional expression and transcription systems and also provides a useful molecular reagent for comparative analysis of this class of enzymes.

Bacteriophage K11 and the host bacterial strain Klebsiella pneumoniae were obtained from the laboratory of Rudolph Hausmann (Freiburg, Germany) via Ian Molineux (University of
Texas, Austin, TX, USA). The phages were propagated and harvested by differential centrifugation as previously described for bacteriophage T7 (22), and DNA was isolated from the phage particles by phenol extraction (21). The K11 RNAP gene was amplified from phage DNA by polymerase chain reaction (PCR) using Pfu DNA Polymerase (Stratagene, La Jolla, CA, USA) and the primers MR113 (CCGCTCGAGATGAACGCATTAAACATTGG) and MR114 (CGGAATTCTTACGCAAACGCGAAGTCAGA). These

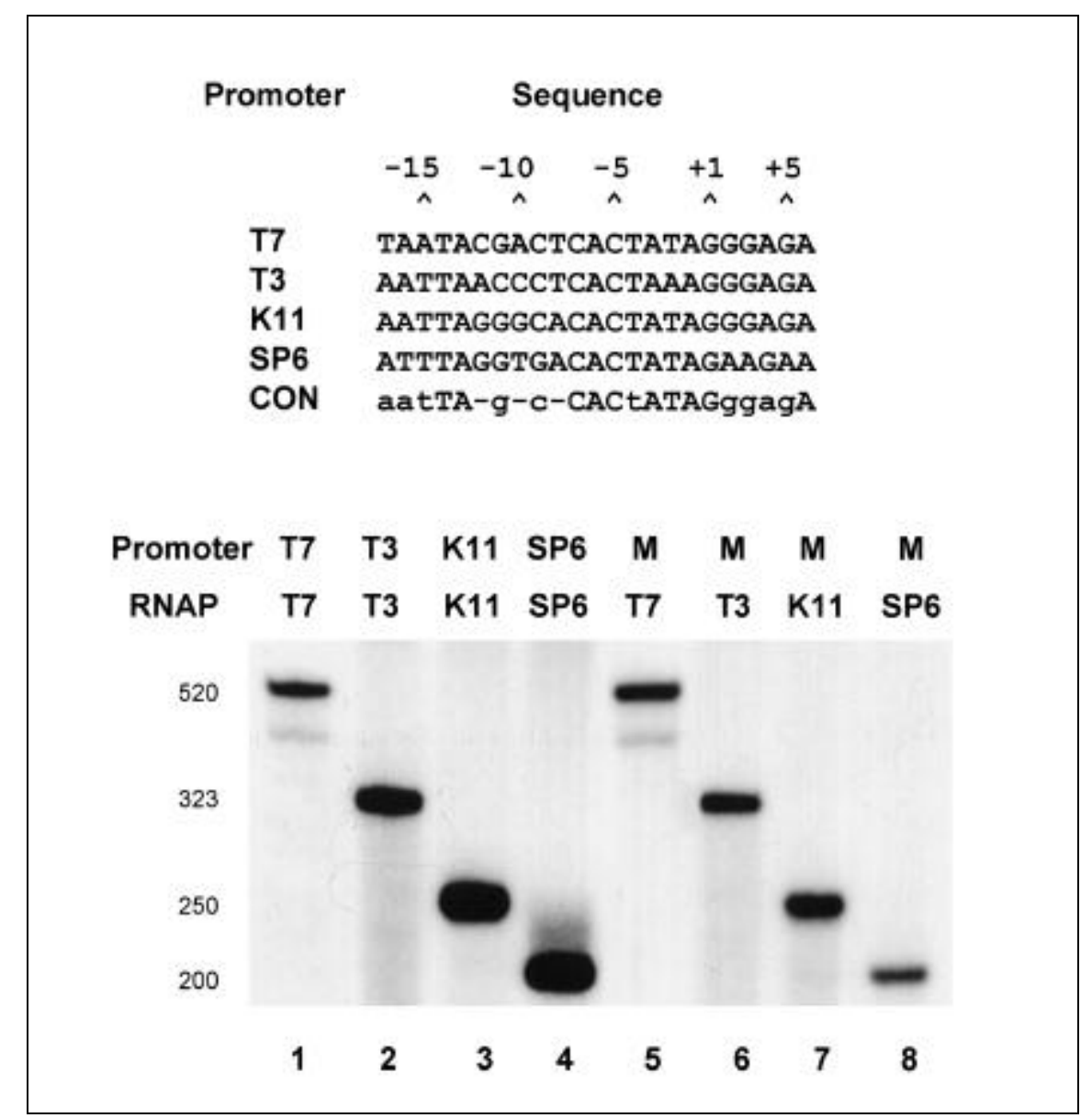

Figure 2. Specificity of K11 RNA polymerase. (Top panel) Promoter sequences for the T7, T3, SP6 and K11 RNAPs are aligned; positions are numbered relative to the start site for transcription $(+1)$. A consensus phage promoter sequence is indicated $(\mathrm{CON})$; note that the region from -8 to -12 is not well-conserved (13). (Bottom panel) Plasmids carrying phage promoters were transcribed by the RNAP indicated, and the products were resolved by electrophoresis (10). The plasmid template utilized, the restriction enzyme used to linearize the plasmid, and the expected sizes of the runoff product from each promoter are as follows. T7: pBluescript II ${ }^{\circledR} \mathrm{SK}+$ (Stratagene), AflIII and BsmFI, $520 \mathrm{nt}$; T3: pBluescript II SK+, AflIII and BsmFI, 323 nt; K11: pMR104, NdeI, 250 nt; SP6: pDL56, NruI, 200 nt. The reactions shown in lanes 1-4 contained only the template indicated $(1 \mu \mathrm{g})$; reactions shown in lanes 5-8 $(\mathrm{M})$ contained an equal mixture of all 4 templates $\left(0.25 \mu \mathrm{g}\right.$ each). Transcription was carried out for $15 \mathrm{~min}$ at $37^{\circ} \mathrm{C}$ in a volume of $20 \mu \mathrm{L}$ containing $20 \mathrm{mM}$ Tris- $\mathrm{HCl}, \mathrm{pH} 7.9,10 \mathrm{mM}$ magnesium acetate, $1 \mathrm{mM}$ dithiothreitol (DTT), $0.05 \%$ Tween $^{\circledR} 20,0.5 \mathrm{mM}$ ATP, GTP, CTP and UTP, $0.1 \mu \mathrm{Ci}$ [ $\left.\alpha-32 \mathrm{P}\right] \mathrm{ATP}, 4-20 \mathrm{ng}$ RNAP and 1 $\mu \mathrm{g}$ template. pDL56 contains the SP6 promoter from the GEM $^{\circledR}$ series (Promega, Madison, WI, USA) in a pBR322-derived background (D. Lyakhov and W.T. McAllister, unpublished). 
primers are complementary to the first 7 and last 7 codons of the K11 RNAP gene (underlined). For the complete sequence of the K11 RNAP gene, see Reference 4 . The primers also introduce an upstream XhoI site and a downstream EcoRI site (italics). The amplification products were digested with $X h o I$ and EcoRI and cloned into the corresponding sites of pBH161 (10), replacing the T7 RNAP gene in that vector. In the resulting plasmid (pMR105), the K11 RNAP gene is fused to a hexameric histidine leader sequence and is positioned downstream from an inducible lac promoter. The predicted N-terminal amino acid sequence of the fusion protein is: MGSSHHHHHHSSGLVPRGSHMLEMNALNIG, in which the underlined residues correspond to the first 7 amino acids of K11 RNAP (4). This same arrangement was previously utilized to express and purify His-tagged forms of the T7, T3 and SP6 RNAPs (10).

Cultures containing pMR105 were propagated and induced with isopropyl-1-thio- $\beta$-D-galactoside (IPTG), and the histidine-tagged RNAP was purified by affinity chromatography using $\mathrm{Ni}^{++}$-agarose beads as previously described in He et al. (10) and Temiakov et al. (25). The yield and purity of K11 RNAP were similar to those previously obtained with other histidine-tagged RNAPs (Figure 1).

The phage RNAPs are highly specific for their own promoters. Each of these promoters is related to a conserved 23-bp sequence that extends from -17 to +6 (where +1 is the start site for transcription; see Figure 2). To characterize the activity and specificity of the K11 RNA polymerase, a plasmid template that carries the K11 promoter was constructed. The synthetic oligomers MR119 (CCGAAGCTTAATTAGGGCACACTATAGGGAGATCTAGAGC) and MR120 (GCTCTAGATCTCCCTATAGTGTGCCCTAATTAAGCTTCGG) contain the K11 promoter sequence (bold; see Reference 3) flanked by HindIII and XbaI sites (underlined). These oligomers were annealed together, digested with $H i n \mathrm{dIII}$ and $X b a \mathrm{I}$, and the fragment was cloned into the corresponding sites of pUC19 to generate pMR104.

As shown in Figure 2, digestion of pMR104 with NdeI and transcription by K11 RNAP resulted in the efficient synthesis of a transcript of the expected size (250 nucleotide [nt], lane 3). Like the T7, T3 and SP6 RNAPs, the K11 RNAP is highly specific for its own promoter, as demonstrated by the observation that it utilized only this promoter in the presence of a mixture of templates that also contained promoters for the other 3 RNAPs (Figure 2, lane 7).

Due to their structural simplicity, the phage RNAPs have provided an attractive model system to study the mechanisms of transcription. Of particular interest has been the manner in which these enzymes recognize their specific promoters. For the T7 and T3 RNAPs, it has been demonstrated that a specificity loop (amino acid residues 
742-773) that projects into the DNAbinding cleft is required for specific recognition of base pairs in the region from -8 to $-11(14,18,20)$. A comparison of promoter sequences for the T7, T3 and SP6 K11 RNAPs indicates that, whereas most positions of the promoter are conserved, this region is divergent (Figure 2). To determine whether we could switch the specificity of the T7 or K11 RNA polymerases, we attempted to swap the region of the T7 RNAP gene that encodes the specificity loop with the corresponding region of the K11 RNAP gene (19). While the resulting enzyme retained nonspecific catalytic activity [as assessed by the synthesis of poly(rG) on a poly $(\mathrm{dC})$ template] it was not active in promoterdependent transcription from either a $\mathrm{T} 7$ or a K11 promoter (19). This result suggests that swapping of the loop perturbs the structure of the RNAP in a manner that prevents promoter recognition in a general manner, or that other regions of the RNAP may also be involved in promoter specificity.

\section{REFERENCES}

1.Arnaud, N., V. Cheynet, G. Oriol, B. Mandrand and F. Mallet. 1997. Construction and expression of a modular gene encoding bacteriophage T7 RNA polymerase. Gene 199:149156.

2.Davanloo, P., A.H. Rosenberg, J.J. Dunn and F.W. Studier. 1984. Cloning and expression of the gene for bacteriophage T7 RNA polymerase. Proc. Natl. Acad. Sci. USA 81:2035-2039.

3.Dietz, A. 1985. Untersuchungen zur evolution von verwandten des phagen $\mathrm{T} 7$ durch vergleichende DNA-basensequenzanalyse. Doctoral Thesis, University of Freiburg, Freiburg, Germany.

4.Dietz, A., H.J. Weisser, H. Kossel and R. Hausmann. 1990. The gene for Klebsiella bacteriophage K11 RNA polymerase: sequence and comparison with the homologous genes of phages T7, T3, and SP6. Mol. Gen. Genet. 221:283-286.

5.Durbin, R.K. 1999. Gene expression systems based on bacteriophage T7 RNA polymerase, p. 10-45. In J.M. Fernandez and J.P. Hoeffler (Eds.), Gene Expression Systems-Using Nature for the Art of Expression. Academic Press, San Diego.

6.Ellinger, T. and R. Ehricht. 1998. Single-step purification of T7 RNA polymerase with a 6histidine tag. BioTechniques 24:718-720.

7.Fuerst, T.R., E.G. Niles, F.W. Studier and B. Moss. 1986. Eukaryotic transient-expression system based on recombinant vaccinia virus that synthesizes bacteriophage T7 RNA polymerase. Proc. Nat. Acad. Sci. USA 83:8122-8126.

8.Guatelli, J.C., K.M. Whitfield, D.Y. Kwoh, K.J. Barringer, D.D. Richman and T.R. Gingeras. 1990. Isothermal, in vitro amplification of nucleic acids by a multienzyme reaction modeled after retroviral replication. Proc. Nat. Acad. Sci. USA 87:1874-1878.

9.Hausmann, R. 1988. The T7 group, p. 259289. In R. Calendar (Ed.), The Bacteriophages. Plenum Press, New York.

10.He, B., M. Rong, D.L. Lyakhov, H. Gartenstein, G.A. Diaz, R.C. Castagna, W.T. McAllister and R.K. Durbin. 1997. Rapid generation and purification of mutant phage RNA polymerases. Protein Expr. Purif. 9:142151.

11.Jorgensen, E.D., R.K. Durbin, S.S. Risman and W.T. McAllister. 1991. Specific contacts between the bacteriophage T3, T7, and SP6 RNA polymerases and their promoters. J. Biol. Chem. 266:645-651.

12.Kotani, H., Y. Ishizaki, N. Hiraoka and A. Obayashi. 1987. Nucleotide sequence and expression of the cloned gene of bacteriophage SP6 RNA polymerase. Nucleic Acids Res. 15:2653-2664.

13.McAllister, W.T. 1993. Structure and function of the bacteriophage T7 RNA polymerase (or, the virtues of simplicity). Cell Mol. Biol. Res. 39:385-391.

14.McAllister, W.T. 1997. Transcription by T7 RNA polymerase, p. 15-25. In F. Eckstein and D. Lilley (Eds.), Nucleic Acids and Molecular Biology. Springer, Berlin.

15.Milligan, J.F. and O.C. Uhlenbeck. 1989. Synthesis of small RNAs using T7 RNA polymerase. Methods Enzymol. 180:51-62.

16.Molineux, I.J. 1999. Bacteriophage T7 and related bacteriophages, p. 1388-1396. In R.G. Webster and A. Granoff (Eds.), Encyclopedia of Virology. Academic Press, New York.

17.Morris, C.E., J.F. Klement and W.T. McAllister. 1986. Cloning and expression of the bacteriophage T3 RNA polymerase gene. Gene 41:193-200.

18.Raskin, C.A., G.A. Diaz, K. Joho and W.T. McAllister. 1992. Substitution of a single bacteriophage $\mathrm{T} 3$ residue in bacteriophage $\mathrm{T} 7$ RNA polymerase at position 748 results in a switch in promoter specificity. J. Mol. Biol. 228:506-515

19.Rong, M. 1998. Characterization of promoter specificity determinants and template requirements of T7 RNA polymerase. Doctoral Thesis, State University of New York, Brooklyn, NY.

20.Rong, M., B. He, W.T. McAllister and R.K. Durbin. 1998. Promoter specificity determinants of T7 RNA polymerase. Proc. Nat. Acad. Sci. USA 95:515-519.

21.Sambrook, J., E.F. Fritsch and T. Maniatis. 1989. Molecular Cloning: A Laboratory Manual, 2nd ed., CHS Laboratory Press, Cold Spring Harbor, NY.

22.Studier, F.W. 1979. Relationships among different strains of T7 and among T7-related bacteriophages. Virology 95:70-84.

23.Studier, F.W., A.H. Rosenberg, J.J. Dunn and J.W. Dubendorff. 1990. Use of T7 RNA polymerase to direct expression of cloned genes. Methods Enzymol. 185:60-89.
24.Tabor, S. and C.C. Richardson. 1985. A bacteriophage T7 RNA polymerase/promoter system for controlled exclusive expression of specific genes. Proc. Nat. Acad. Sci. USA 82:1074-1078.

25.Temiakov, D., P.E. Karasavas and W.T. McAllister. Characterization of T7 RNA polymerase protein:DNA interactions during the initiation and elongation phases. In A.A. Travers and M. Buckle (Eds.), Protein:DNA Interactions: A Practical Approach. Oxford University Press, Oxford (In press).

26.Zhou, Y., T.J. Giordano, R.K. Durbin and W.T. McAllister. 1990. Synthesis of functional mRNA in mammalian cells by bacteriophage T3 RNA polymerase. Mol. Cell Biol. 10:4529-4537.

This work was supported by Grant No. GM38147 to W.T.M. from the National Institutes of Health and was submitted to the State University of New York in partial fulfillment of the requirements for the doctoral degree of M.R. Address correspondence to William T. McAllister, Department of Microbiology and Immunology, Box 44, SUNY Health Science Center at Brooklyn, 450 Clarkson Avenue, Brooklyn, NY 112032098, USA. Internet:pogo51@aol.com

Received 26 April 1999; accepted 28 June 1999.

\section{Minqing Rong, Ray Castagna and William T. McAllister SUNY Health Science Center at Brooklyn Brooklyn, NY, USA}

